\title{
Hubungan Imunoekspresi NF-kB dengan Sinus Rokitansky Aschoff pada Kolesistitis Kronik
}

\author{
Herry Yulianti, Bethy S. Hernowo \\ Departemen Patologi Anatomi Fakultas Kedokteran Universitas Padjadjaran Bandung \\ Rumah Sakit Dr. Hasan Sadikin Bandung
}

\begin{abstract}
Abstrak
Karsinoma kandung empedu relatif jarang, tetapi merupakan penyakit yang sangat mematikan. Keganasan kandung empedu merupakan 3-4\% dari seluruh lesi ganas dan menempati urutan ke-5 di antara tumor sistem pencernaan. Karsinoma kandung empedu sulit dideteksi dan didiagnosis pada stadium awal, karena biasanya gejalanya sangat sedikit atau tanpa gejala. Oleh karena itu sangat penting menegakkan diagnosis secara dini dan mendeteksi pasien risiko tinggi, termasuk batu dan riwayat kolesistitis kronik. Kolesistitis kronik merupakan peradangan kronik pada kandung empedu dan disertai kolelitiasis pada lebih dari $90 \%$ kasus. Batu empedu merupakan faktor etiologi yang penting pada karsinoma kandung empedu. Pada gambaran histopatologi kolesistitis kronik ditemukan sinus Rokitansky Aschoff. Pendekatan genetik telah membuktikan komponen inflamasi berperan dalam karsinogenesis, seperti primary inflammatory cytokines, interleukin-1 (IL-1), tumor necrosis factor (TNF), IL-6, dan nuclear factorkappaB (NF-kB). Tujuan penelitian ini untuk mengetahui hubungan imunoekspresi NF-kB dengan sinus Rokitansky Aschoff pada kolesistitis kronik. Metode penelitian adalah potong lintang terhadap 30 kasus kolesistitis kronik yang berasal dari Departemen Patologi Anatomi Rumah Sakit Dr. Hasan Sadikin Bandung/Fakultas Kedokteran Universitas Padjadjaran tahun 2010-2011. Potongan blok parafin dari jaringan kolesistitis kronik setebal $4 \mu \mathrm{m}$ diwarnai dengan hematoksilin eosin untuk evaluasi gambaran histopatologi dan pemeriksaan imunohistokimia menggunakan polyclonal NF-kB antibody. Perhitungan sel yang imunoreaktif dilakukan di bawah mikroskop cahaya dengan pembesaran 400x, dihitung rata-rata pada 5 tempat. Hasil penelitian menunjukkan hubungan yang signifikan antara imunoekspresi NFkB dan sinus Rokitansky Aschoff $(p=0,000)$. Simpulan, terdapat hubungan imunoekspresi NFkB dengan sinus Rokitanski Aschoff, semakin tinggi imunoekspresi NFkB semakin banyak sinus Rokitansky Aschoff. [MKB. 2014;46(2):106-11]
\end{abstract}

Kata kunci: Kolesistitis kronik, NFkB, sinus Rokitansky Aschoff

\section{Correlation between Immunoexpression of NF-kB and Rokitansky Aschoff Sinuses in Chronic Cholecystitis}

\begin{abstract}
Carcinoma of the gallbladder is relatively uncommon but it is a very lethal disease. Gallbladder cancer constitutes $3-4 \%$ of all malignant lesions and ranks 5 th among the digestive system tumors. Gallblader carcinoma is difficult to detect and diagnose in early stage because it usually has very slight symptoms or asymptomatic. It becomes increasingly necessary to make early diagnosis and identification of high-risk patient,as well as gallstone and history of chronic cholecystitis. Chronic cholecystitis is a chronic inflammation of gallbladder associated with cholelithiasis in more than $90 \%$ of cases. Cholelithiasis is one of the important etiological factors in carcinoma of the gallbladder. The histological examination of chronical cholecystitis shows the presence of Rokitansky Aschoff sinuses. Genetic approaches have proven that the components of inflammation such as primary inflammatory cytokines, interleukin-1 (IL-1), tumor necrosis factor (TNF), IL-6 and nuclear factor-kB (NF-kB) play the key roles in carcinogenesis. The purpose of this study was to understand the correlation between the immunoexpression of NF-kB and Rokitansky Aschoff sinuses in chronic cholecystitis. The method was cross sectional of 30 cases of chronic cholecystitis from Department of Pathology Anatomy of Dr. Hasan Sadikin General Hospital Bandung/Faculty of Medicine Universitas Padjadjaran in 2010-2011. A section from $4 \mu \mathrm{m}$-thick paraffin embedded tissue of chronic cholecystitis was stained with hematoxylin eosin for histopatological evaluation and immunohistochemical using polyclonal NF-kB antibody. Immunoreactive cells was counted in five tumor areas of 400x field by light microscopy. The result showed a significant correlation between the immunoexpression of NFkB and Rokitansky Aschoff sinuses $(p=0.000)$. In conclusion, there is a correlation between immunoexpression of NFkB and Rokitansky Aschoff sinuses because as the immunoexpression of NFkB increase, more Rokitansky Aschoff sinuses will be formed. [MKB. 2014;46(2):106-11]
\end{abstract}

Key words: Chronic cholecystitis, NFkB, Rokitansky Aschoff sinuses

Korespondensi: Herry Yulianti, dr., Sp.PA, Jalan Guntursari III No 21 Buah Batu Bandung 40264, mobile 0811223103, e-mail herryyulianti@yahoo.com 


\section{Pendahuluan}

Kolesistitis kronik adalah peradangan kronik pada kandung empedu, dan 90\% disertai kolelitiasis. Kolesistitis kronik jarang ditemukan tanpa disertai batu empedu, walaupun batu murni kolesterol dan calcium bilirubinate dapat ditemukan juga tanpa disertai dengan inflamasi. ${ }^{1,2}$ Mikroskopis kolesistitis yang kronik memperlihatkan berbagai tingkat infiltrasi sel-sel limfosit dan fibrosis pada mukosa dan sinus Rokitansky Aschoff akibat peningkatan tekanan di dalam lumen. ${ }^{1}$ Batu dan inflamasi kronik merupakan faktor risiko terjadi karsinoma kandung empedu. ${ }^{3}$ Penelitian mutakhir membuktikan hubungan erat antara inflamasi dan neoplasia, termasuk inflammatory bowel disease pada kolon, gastritis yang disertai Helicobacter pylori, dan gallbladder carcinoma yang sering dilatarbelakangi oleh inflamasi kronik. ${ }^{4}$ Chronic cholecystitis-carcinoma sequence merupakan pathway yang paling penting pada gallbladder carcinogenesis. ${ }^{4-9}$

Gallbladder carcinoma (GBC) merupakan keganasan traktus biliaris yang paling banyak, terdapat $1 \mathrm{k}$. 3\% dari seluruh tumor. Gallbladder carcinoma (GBC) sulit dideteksi pada stadium dini oleh karena biasanya bersifat asimtomatik dan gejalanya sama dengan kolesititis kronik. Gallbladder carcinoma adalah salah satu tumor sangat mematikan dengan angka kelangsungan hidup 5 tahun $<2,1 \%$ dan tidak sensitif terhadap radioterapi dan kemoterapi, sehingga diperlukan diagnosis dini dengan mengidentifikasi pasien yang berisiko tinggi sehingga dapat dilakukan kolesistektomi sebagai profilaksis. ${ }^{10,11}$

Pendekatan secara genetik telah membuktikan komponen inflamasi mempunyai peranan dalam karsinogenesis, seperti primary inflammatory cytokines interleukin-1 (IL-1), tumor necrosis factor(TNF),IL-6, dannuclearfactor-kappaB(NF$\mathrm{kB})$. Nuclear factor-kappaB (NF-kB) mengatur ekspresi gen yang terlibat pada berbagai proses yang mempunyai peran dalam perkembangan serta progresivitas kanker seperti proliferasi, migrasi, dan apoptosis. Nuclear factor-kappaB bukan suatu single gen, tetapi famili yang erat hubungannya dengan faktor transkripsi, termasuk 5 gen $N F-k B 1$ (p50/p105), NF-kB2 (p52/p100), RelA (p65), c-Rel, dan RelB. ${ }^{12,13}$ Nuclear factorkappaB terlihat pada semua sel yang teraktivasi, yang mengatur ekspresi dari bermacam target gen yang mempromosi proliferasi sel, pengaturan imun, respons inflamasi, dan juga berkontribusi dalam patogenesis berbagai penyakit termasuk juga keganasan. Nuclear factor-kappaB signaling pathway diregulasi oleh inhibitor kappaB (IkB) family. Nuclear factor-kappaB banyak terdapat dalam sitoplasma, NF-kB akan berikatan dengan
IkB yang akan menahan NF-kB tetap berada dalam sitoplasma. Aktivasi NF-kB pathway merupakan salah satu kunci mekanisme kelangsungan hidup pada berbagai tipe keganasan. Banyak penelitian yang menunjukkan bahwa NF-kB dapat memblok apoptosis dengan mengatur protein anti-apoptosis seperti inhibitor of apoptosis protein (IAPs). ${ }^{5}$

\section{Metode}

Bentuk penelitian adalah potong lintang terhadap 30 kasus kolesistitis kronik yang terpilih dari pemeriksaan hematoxylin-eosin yang berasal dari Departemen Patologi Anatomi Rumah Sakit Dr. Hasan Sadikin/Fakultas Kedokteran Universitas Padjadjaran Bandung, mulai Januari 2010 sampai Desember 2011.

Dilakukan pengumpulan blok parafin dari 30 sediaan tersebut dan dilakukan pewarnaan $\mathrm{HE}$ dan imunohistokimia NF- $\mathrm{B}$. Imunoekspresi NF- $B$ memberikan hasil positif berdasarkan warna coklat pada sitoplasma dan inti dari sel tumor. ${ }^{13}$ Perhitungan sel imunoreaktif dilakukan di bawah mikroskop cahaya dengan pembesaran 400x, dihitung sel rata-rata yang terwarnai pada 5 tempat. Pewarnaan imunohistokimia NF-B dengan menggunakan rabbit polyclonal to $N F$ kB p65-CHIP Grade (ab7970) (abcam), masingmasing dengan prosedur manual dilanjutkan menggunakan mesin InteliPATH FLX automated slide stainer. Blok parafin yang telah dikumpulkan dipotong dengan mikrotom dengan ketebalan $4 \mu \mathrm{m}$ dan kemudian diletakkan pada object glass yang telah dilakukan coating, kemudian dilakukan pewarnaan imunohistokimia dengan metode avidin-biotin. Dilakukan deparafinisasi dengan xylol selama $3 \times 5$ menit, rehidrasi dengan etanol selama $3 \times 5$ menit, kemudian dengan alkohol $90 \%, 80 \%, 70 \%$ selama 5 menit, bilas dengan air yang mengalir, rendam dalam larutan hydrogen peroxidase 3\% selama masing-masing 5 menit. Bilas dengan akuades, lakukan antigen unmasking retrieval dengan bufer sitrat yang mendidih selama $2 \times 5$ menit. Dinginkan dalam suhu ruangan selama 15 menit. Inkubasi dengan $\mathrm{H}_{2} \mathrm{O}_{2}, 0,3 \%$ dalam metanol selama 10 menit. Bilas dengan phosphat buffered saline (PBS). Setelah diteteskan blocking serum sebesar 1,5\% kemudian diinkubasi selama 5 sampai 10 menit. Selanjutnya diteteskan antibodi primer rabbit polyclonal to NF-kB p65 antibody-ChIP Grade (ab 7970) dengan pengenceran 1:200, kemudian di inkubasi selama 60 menit. Bilas dengan PBS selama $3 \times 5$ menit, kemudian diteteskan antibodi sekunder TrekAvidin universal link (Biocare Medical), dan diinkubasi pada suhu ruangan selama 20 menit, selanjutnya diteteskan chromogen, kemudian 
di inkubasi selama 5-10 menit. Setelah dibilas dengan air mengalir selama 5 menit, dilakukan counterstain dengan mayer hematoxylin selama 2 menit, kemudian dicuci dengan air mengalir. Setelah dilaksanakan dehidrasi dengan alkohol $70 \%, 80 \%, 90 \%$, dan juga etanol selama 3 menit, kemudian dimasukkan dalam xylol, dan terakhir dilakukan mounting

Penilaian imunoekspresi NFkB dikategorikan berdasarkan persentase sel-sel mukosa kandung empedu yang terwarna coklat pada inti dengan berbagai intensitas.

\section{Hasil}

Selama periode Januari 2010-Desember 2011 di Departemen Patologi Anatomi Rumah Sakit Dr. Hasan Sadikin Bandung terkumpul 35 kasus yang didiagnosis sebagai kolesistitis kronik, dan hanya 30 kasus yang memenuhi kriteria inklusi penelitian ini. Dari hasil pemeriksaan dengan pewarnaan hematoksilin eosin, terdapat sinus Rokitansky Aschoff 0-35 sebanyak 17 kasus dan 36-70 sebanyak 13 kasus. Dari pemeriksaan secara makroskopis terdapat kolesistitis kronik disertai dengan batu sebanyak 27 kasus dan tidak disertai dengan batu 3 kasus. Pada penelitian ini, imunoekspresi NFkB 0-30 sebanyak 17 kasus dan 3-60 sebanyak 13 kasus.

Analisis statistik mempergunakan program SPSS 16 dan hasil pengujian statistik dengan Uji Sommers'd diperoleh nilai $p=0,000 \quad(p<0,05)$. Terdapat korelasi yang sangat bermakna antara

Tabel 1 Karakteristik Penderita

\begin{tabular}{lc}
\hline \multicolumn{1}{c}{ Karakteristik } & n \\
\hline Usia rata-rata & $47(26-65)$ \\
Jenis kelamin & \\
$\quad$ Laki-laki & 9 \\
$\quad$ Perempuan & 21 \\
Sinus Rokitansky & \\
Aschoff & \\
0-35 & 17 \\
36-70 & 13 \\
Kolesistitis kronik & \\
Tanpa batu & 3 \\
Dengan batu & 27 \\
Imunoekspresi NFkB & \\
$0-30$ & 17 \\
31-60 & 13 \\
\hline
\end{tabular}

Tabel 2 Hubungan Imunoekspresi NFkB dengan Sinus Rokitansky Aschoff

\begin{tabular}{ccc}
\hline \multirow{2}{*}{$\begin{array}{c}\text { Imunoekspresi } \\
\text { NFkB }\end{array}$} & \multicolumn{2}{c}{ Sinus Rokitansky Aschoff } \\
\cline { 2 - 3 } & $0-35$ & $36-70$ \\
\hline $0-30$ & 15 & 2 \\
$31-60$ & 2 & 11 \\
\hline
\end{tabular}

imunoekspresi NFkB danjumlah sinus Rokitansky Aschoff, semakin tinggi imunoekspresi NFkB akan semakin banyak sinus Rokitansky Aschoff.

\section{Tabel 3 Hubungan Batu Empedu dengan Imunoekspresi NFkB dan Sinus Rokitansky Aschoff}

\begin{tabular}{lcccc}
\hline \multirow{2}{*}{$\begin{array}{c}\text { Batu } \\
\text { Empedu }\end{array}$} & \multicolumn{2}{c}{$\begin{array}{c}\text { Imunoekspresi } \\
\text { NFkB }\end{array}$} & \multicolumn{2}{c}{$\begin{array}{c}\text { Sinus Rokitansky } \\
\text { Aschoff }\end{array}$} \\
\cline { 2 - 5 } & $0-30$ & $31-60$ & $0-35$ & $36-70$ \\
\hline Positif & 16 & 11 & 16 & 11 \\
Negatif & 1 & 2 & 1 & 2 \\
\hline
\end{tabular}

Keterangan: imunoekspresi NFkB berdasarkan persentase sel yang terwarna coklat dengan berbagai intensitas

\section{Pembahasan}

Pada penelitian ini karakteristik klinikopatologi dari kasus kolesistitis kronik diperoleh gambaran sebagai berikut: penderita laki-laki 9 orang dan wanita 21 orang, rentang usia penderita 26-65 tahun. Kolesistitis kronik tanpa batu sebanyak 3 kasus dan dengan batu sebanyak 27 kasus. Hal

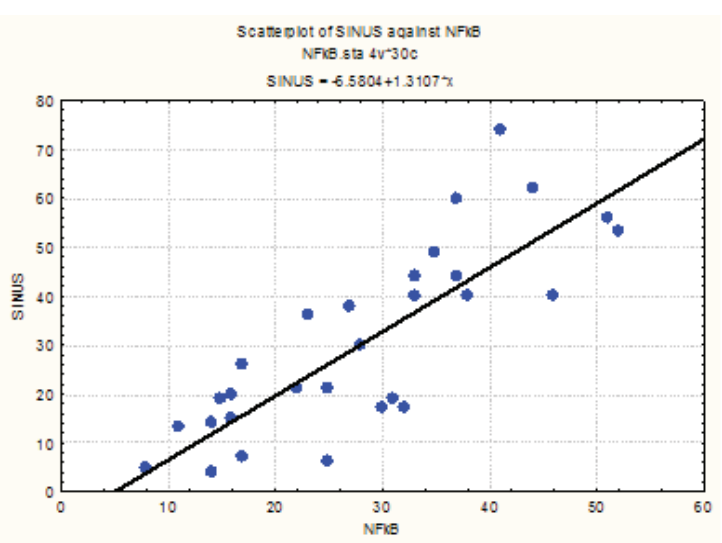

Gambar 1 Hubungan Imunoekspresi NFkB dengan Sinus Rokitansky Aschoff 


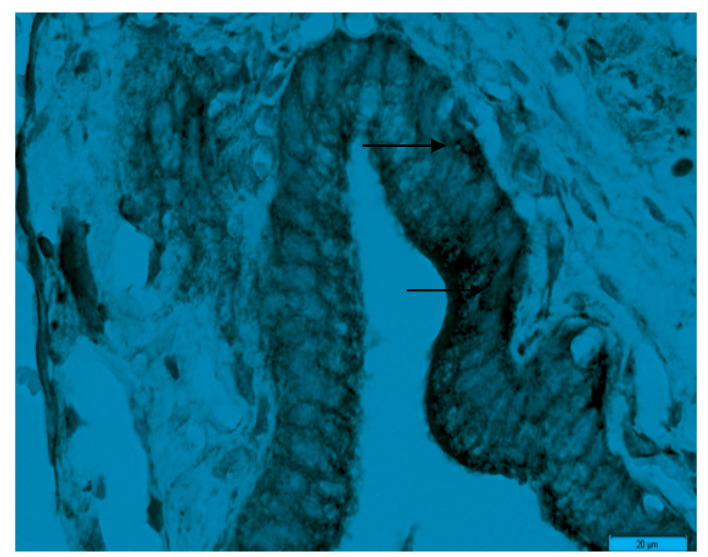

Gambar 2 Imunoekspresi NFkB pada Kolesistitis Kronik. Sitoplasma sel mukosa kandung empedu sebagian besar terwarna coklat dengan intensitas sedang dan sebagian kecil intensitas kuat, beberapa inti sel terwarna dengan intensitas kuat (tanda panah). Pembesaran 400x

ini sesuai dengan penelitian Kumar dkk. ${ }^{2}$ bahwa lebih dari 90\% kasus kolesistitis kronik disertai kolelitiasis.

Pada penelitian hasil imunoekspresi NFkB terlihat pada hampir seluruh sitoplasma dengan intensitas pulasan sedang sampai kuat dan pada sebagian inti sel. Intensitas warna pada inti sel sangat bervariasi dari lemah sampai kuat. Pada penelitian ini yang dikatakan memberikan hasil positif adalah NFkB yang terekspresi pada inti sel. Faktor transkripsi NFkB di dalam sitoplasma dalam keadaan inaktif karena berikatan dengan inhibitor kappa B (IkB). Apabila terjadi aktivasi NFkB oleh enzim IkB kinase (IKK), ikatan tersebut akan terlepas dan juga faktor transkripsi NFkB menjadi aktif dan bertranslokasi ke dalam inti. ${ }^{14}$

Gambaran histopatologi kolesistitis kronik menunjukkan sinus Rokitansky Aschoff sebagai akibat peningkatan tekanan di dalam lumen. Pada penelitian ini, hasil analisis regresi dan korelasi antara variabel imunoekspresi NFkB dan sinus Rokitansky Aschoff memperlihatkan hubungan sangat signifikan, dengan nilai korelasi antara keduanya sangat tinggi, yaitu $0,82(\mathrm{p}=0,000)$.

Hubungan imunoekspresi NFkB dengan batu empedu dan hubungan sinus Rokitansky Aschoff dengan batu empedu pada penelitian ini tidak dapat dianalisis karena jumlah kolesistitis kronik tanpa batu empedu hanya 3 kasus dari 30 kasus, sehingga tidak diketahui hubungan NFkB dengan batu empedu dan hubungan sinus Rokitansky Aschoff dengan batu empedu. Dengan demikian, perlu penelitian lebih lanjut dengan jumlah kasus

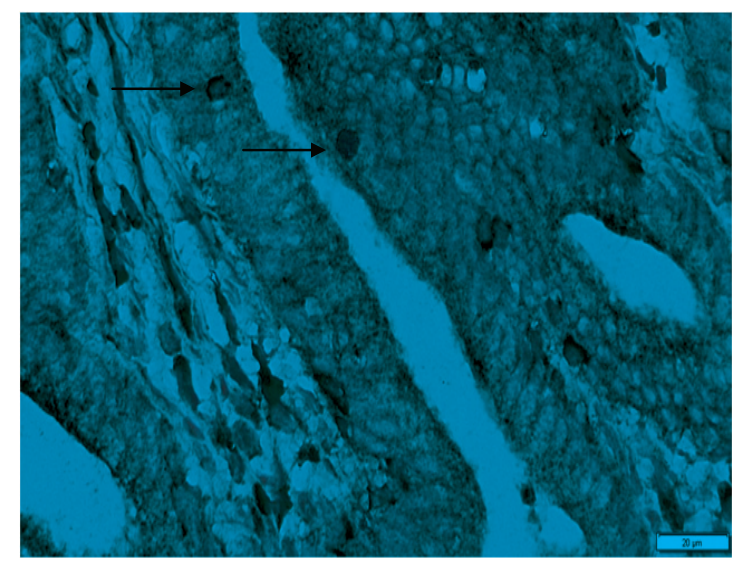

Gambar 3 Imunoekspresi NFkB pada Kolesistitis Kronik. Sitoplasma sel mukosa kandung empedu terwarna coklat dengan intensitas sedang dan inti terwarnai dengan intensitas kuat. Pembesaran 400x

yang lebih besar.

Simpulan, terdapat hubungan imunoekspresi NFkB dengan sinus Rokitanski Aschoff, semakin tinggi imunoekspresi NFkB akan semakin banyak sinus Rokitansky Aschoff.

\section{Daftar Pustaka}

1. Rosai J. Gallbladder and extrahepatic bile duct. Dalam: Houston M, penyunting. Rosai and Ackerman's surgical pathology. Edisi ke10. Edinburgh: Elsevier Mosby; 2011. hlm. 981-97.

2. Kumar V, Abbas AK, Fausto N. The biliary tract. Dalam: Schmitt W, penyunting. Robbins and Cotran pathologic basis of disease. Edisi ke-8. Philadelphia: Elsevier Saunder; 2010. hlm. 882-9.

3. Naqvi SQH, Mangi IH, Dahri FJ, Khaskheli QA, Akhund AA. Frequency of carcinoma of gallbladder in patients with cholelithiasis. GJMS. 2005;3(2):41-3.

4. Yanagisawa N, Yamashita K, KubaT, Okayasu I. Sporadic TP53 transition mutations in chronic cholecystitis are possibly linked to gallbladder carcinogenesis. Anti Cancer Res. 2010;30(11):4443-9.

5. Wang S, Liu Z, Wang L, Zhang X. NFkappaB signaling pathway, inflammation and colorectal cancer. Cell Mol Immunol. 2009;6(5):327-34.

6. Aggarwal B, Shishodia S, Sandur SK, Pandey MK, Sethi G. Inflammation and cancer: how hot is the link? Biochem Pharmacol. 2006;72(11):1605-21. 
7. Colotta F, Allavena P, Sica A, Garlanda C, Mantovani A. Cancer-related inflammation, the seventh hallmark of cancer: links to genetic instability. Carcinogenesis. 2009;30(7):1073-81.

8. Kundu JK, Surh YJ. Inflammation: gearing the journey to cancer. Mutat Res. 2008;659(12):15-30.

9. Karin M. NF-kappaB as a critical link between inflammation and cancer. Cold Spring Harb Perspect Biol. 2012;1(5):a000141.

10. Vijayakusumar A, Vijayakusumar A, Patil V, Mallikarjuna MN, Shivaswamy BS. Early diagnosis of gallbladder carcinoma: an algorithm approach. ISRN Radiology. 2012;2013(2013):1-6.
11. Wasim B, Kafil N, Hadi NI, Afshan G. Age and gender related frequency of cancer in chronic cholelithiasis. Surg Pak. 2010;15(1): $48-51$.

12. Dolcet X, Llobet D, Pallares J, Matias-Guiu $\mathrm{X}$. NF-kB in development and progression of human cancer. Virchows Arch. 2005;446(5): 475-82.

13. Meteoglu I, Erdogdu H, Meydan N, Erkus M, Barutca S. NF-kappaB expression correlates with apoptosis and angiogenesis in clear cell renal cell. Exp Clin Cancer Res. 2008;27:53.

14. Gilmore TD. Introduction to NF-kappaB: players, pathways, perspectives. Oncogen. 2006;25(51):6680-4. 